\title{
Commercial Law and the American Volk: A Note on Llewellyn's German Sources for the Uniform Commercial Code
}

\author{
James Whitman
}

\section{INTRODUCTION}

American commercial law is largely the creation of America's most eccentric legal philosopher. Karl Llewellyn was the principal author of the Uniform Commercial Code (U.C.C.). ${ }^{1}$ He gave the Code an often baffling jurisprudential framework: The U.G.C. regularly refuses to supply substantive rules. Instead, with startling frequency, the Code directs courts to determine whether the parties in a given commercial dispute have acted "reasonably"2 or in accordance with "customs" and "usages of trade"s that are nowhere specified or described in the Code itself. The Code's routine use of these vague directives has irritated some commentators ${ }^{4}$ and thrilled many others. ${ }^{5}$ Almost as soon as it appeared, a body of scholarly commentary began to grow up around Llewellyn's strangely indefinite Code, ${ }^{6}$ and scholars continue to search for the intellectual sources of the

1. For Llewellyn's role in the drafting of the U.C.C., sce Schnader, A Short History of the Preparation and Enactment of the Uniform Commercial Code, 22 U. Mramt L. Rrv. 1, 4 (1967); Gilmore, In Memoriam: Karl Llewellyn, 71 YAl.: L.J. 813, 814-15 (1962); Danzig, A Comment on the Jurisprudence of the Uniform Commercial Code, 27 SraN. L. Rev. 621 (1975); and most recently Wiseman, The Limits of Vision: Karl Llewellyn and the Merchant Rules, 100 HARv. L. Rev. 465 (1987).

2. See, e.g., U.C.C. \$ 3-511(1) (1978) ("reasonable diligence"); U.C.C. § 2-209(5) ("reasonable notification"); U.C.C. \$ 4-406(1) (statements of account made "in a reasonable manner"); $c f$. U.C.C. $\S 1-204$ (definition of "reasonable time").

3. See U.C.C. § 1-102(2)(b) (U.C.C. intended, inter alia, "to permit the continued expansion of commercial practices through custom [and] usage . . ..") Cf., e.g., U.C.C. \& 3-503(2) ("reasonable time" to be determined in part by "any usage of banking or trade"); U.C.C. § 2-504(b) (seller must provide shipping documents required "by usage of trade").

4. See, e.g., Danzig, supra note 1, at 629 (Code's approach "disturbing on several counts"); Note, Disparate Judicial Construction of the Uniform Commercial Code-The Need for Federal Legislation, 1969 UrAH L. Rkv. 722, 734-35 (Code's broad generalities hinder uniformity); Hillinger, The Article 2 Merchant Rules: Karl Llewellyn's Attempt to Achieve the Good, The True, and The Beautiful in Commercial Law, 73 Gro. L.J. 1141, 1145-46 (1985) (Llewellyn's conception for the U.C.C. unworkable).

5. See, e.g., J. White \& R. Summers, Uniform Commerciat. Cone 20 (1980) (U.C.C. allows courts to "escape the ancient dilemma of either adhering to the legal rule and doing an inequity, or of doing equity but in an unlaw-like fashion"); Franklin, On the Legal Method of the Uniform Commercial Code, 16 LAw \& ConTrmp. Probs. 330, 331 (1951) (U.C.C. avoids "the mechanistic conception of codification. . . a merely military conception of codification").

6. For citations to early literature, see, e.g., Hillman, Construction of the Uniform Commercial Code: U.C.C. Section 1-103 and "Code" Methodology, 18 B.C. Innus. \& Com. L. Rt.v. 655 (1977). 
Code in the peculiarities of Llewellyn's personality ${ }^{7}$ and in the history of his contribution to the decade-long drafting process of the U.C.G. ${ }^{8}$

Despite these many scholarly efforts, no consensus about the meaning of Llewellyn's work has emerged. Some commentators have seen the Code as the product of a carefully conceived philosophical program, as part of a campaign to "liberalize" commercial law, ${ }^{9}$ or to put some form of philosophical realism into practice. ${ }^{10}$ Others have seen the Code less as a calculated philosophical effort than as a piece of historical revivalism in commercial law, an attempt; through the ratification of trade usage, to bring back to life the medieval law merchant, which was based on commercial customs and practices. ${ }^{11}$ As Homer Kripke, one of Llewellyn's collaborators, put it, Llewellyn's Code was intended "to correct some false starts, to point the law in the indicated directions, and to restore the law merchant as an institution for growth only lightly kept in bounds by statute."12 These divergent explanations coexist unreconciled in the Llewellyn literature; no scholar has been able to explain what relation Llewellyn's commitment to liberalization might bear to his love of the historic law merchant. Llewellyn's biographer has simply. concluded that no "clearcut answer" can be given to the question of what part Llewellyn's jurisprudential ideas played in the shaping of the Code. ${ }^{13}$ Forty years of debate have thus left us with the picture of a Code created by an inexplicable original genius.

Of course Llewellyn was an original, and perhaps ultimately inexplicable, genius. Nevertheless, this Note will argue that Llewellyn's conception for the Code has a coherence that commentators have not yet understood. Llewellyn's idea of "reasonableness," his love for the "law merchant" and his peculiar ambitions for a political transformation of the United States all had common roots in little-known corners of German Romantic and post-Romantic legal thought, ${ }^{14}$ and in particular in the work of Levin

\footnotetext{
7. See Hillinger, supra note 4.
}

8. For a detailed history of Llewellyn's role in the drafting of the U.C.C, see Wiseman, supra note 1. For recent calls for study of the origins of the U.C.C., see J. Whrte \& R. Summers, supra note 5, at 5-6; Williams, Book Review, 97 HaRv. L. REv. 1495, 1496 n.6 (1984). Interest in the origins of the U.C.C. is reflected in the multi-volume reprint by the American Law Institute of all versions of the Code up to that of 1962. UNiform Commercial. CoDE: Drafis (E. Kelly ed. 1984).

9. See J. Whrtr. \& R. Summers, supra note 5, at 15-16 ("liberalizing spirit" of the Code's provisions on commercial reasonableness and good faith).

10. See Wiseman, supra note 1.

11. For the customary character of medieval commercial law, see Pohlmann, Die Quellen des Handelsrechts, in 1 HANDBUC:H DER QUEILI.EN UND LITERATUR DER NEUEREN EUROPÄISCHEN PRIVATRkithtsciss:hic:HIt: 801, 801-02 (1973). For a discussion of early-modern commercial law, which lost, in some measure, its customary character, see Scherner, Die Wissenschaft des Handelsrechts, in 2 HANdBUC:H DER Quki.l.EN UND LITERATUR DeR NEUEREN EUROPÄISCHEN PRIVATREC:HISCiES:HIC:HIV: 797 (1977).

12. Kripke, The Principles Underlying the Drafting of the Uniform Commercial Code, $1962 \mathrm{U}$. It.I. L.F. 321, 331.

13. W. Twininc;, Kart. Ll.fwfi.t.yn and the Real.ist Movement 271 (2d. ed. 1985).

14. Scholars have suggested a variety of German influences on Llewellyn. See, e.g., Herman, Llewellyn the Civilian: Speculations on the Contribution of Continental Experience to the Uniform 
Goldschmidt, a leading nineteenth-century commercial lawyer who has by and large fallen into obscurity. Llewellyn scholars have sometimes noted that Llewellyn must have been somehow inspired by Goldschmidt's ideas. Llewellyn was fond of quoting a passage from Goldschmidt, a passage which most commentators have found almost incomprehensible. This puzzling passage-which Llewellyn's biographer has despairingly described as an "apparent headlong plunge into metaphysics"18 — reads:

Every fact-pattern of common life, so far as the legal order can take it in, carries within itself its appropriate, natural rules, its right law. This is a natural law which is real, not imaginary; it is not a creature of mere reason, but rests on the solid foundation of what reason can recognize in the nature of man and of the life conditions of the time and place: it is thus not eternal nor changeless nor everywhere the same, but is in-dwelling in the very circumstances of life. The highest task of law-giving consists in uncovering and implementing this immanent law. ${ }^{16}$

Several Llewellyn scholars have suggested that this strange passage about "immanent law" expresses the jurisprudential conception at the heart of the U.C.C., that Llewellyn believed that finding the "immanent law" of the transaction somehow corresponded to deciding whether the parties had acted "reasonably" and in conformity with "the law merchant."17 But no scholar has been able to explain what Llewellyn thought "immanent law" to be, or why that "immanent law" should embody either realism or trade usage.

Commercial Code, 56 Tul. L. Rrv. 1125, 1135 (1982) (Jhering an influence on Llewellyn). Although Jhering had some influence on all American legal realists, see, Kantorowicz, Some Rationalism about Realism, 43 YA1.: L.J. 1240, 1241-42 (1934), he could hardly have provided the direct inspiration for the U.C.C., since he had little to say about codification as such. For a survey of Jhering's thought, see H. Lance, Die. Wandi.ungen Jhlikincs in stinkr Auffassung; vom Recht (1927). The influence of Savigny has been suggested by, e.g., Franklin, supra note 5, at 340. As this Note will show, Llewellyn owed his ideas primarily to Savigny's opponents, the Germanisten of the early nineteenth century.

15. W. Twinine; supra note 13, at 217.

16. K. Li.kwhil.yn, Thi Common Law Trantrion 122 (1960) [hereinafter Common Law Tradrmon], (quoting Goldschmidt, Preface to Kritik des Eintwurfs eines Handelsgesetzbuchs, 4 KRITISCHE ZrITSCHRIFI F.D. (iESAMMTE: ReChISWISSENSC:HAFT 289 (1857) (hereinafter Kritik]). Llewellyn misidentified this quote. It does not appear either in the article cited in THE COMmON LAW TRADIrION or in the separate printing of the same article that appeared in 1857. Rather, the quote appears in the third and later editions of a different work of Goldschmidt's: 1 L. Gol.DSCKMIDT, HANDBuC:H DFS HaNDEisR:CHTS 302 (3d ed. 1875): "[J]eder Thatbestand des Gemeinlebens, soweit er der Rechtsordnung zugänglich ist, trägt seine angemessenen, natürlichen Rechtssäıze, sein jus aequum, in sich. . . . Dieses wahre, nicht eingebildete, nicht aus der Vernunft geschöpfte, sondern auf der vernünftig erkannten Natur des Menschen und seiner derzeitigen Lebensverhältnisse, als seiner realen Grundlage beruhende, daher auch nicht ewige und unveränderliche noch überall gleiche Naturrecht ist somit den menschlichen Lebensverhältnissen immanent. . . . Die höchste Aufgabe der Rechtsbildung besteht in der Aufdeckung und Durchführung des immanenten Rechts."

17. See, e.g., W. Twininci, supra note 13; at 224-25; Danzig, supra note 1, at 624-25; Williams, supre note 8, at 1498-99. Cf. Corbin, A Tribute to Karl Llewellyn, 71 YA1.1: L.J. 805, 811 (1962). 
This Note will trace the intellectual history of Levin Goldschmidt's "immanent law," showing what mark the tradition to which Goldschmidt belonged left on the U.C.C. The idea of "immanent law" had a complex association with the customary law merchant in Germany, as well as an association with occasionally mystical Romantic nationalist ideas for popular rule. Llewellyn's design for the U.C.C. incorporated much of this German "immanent law" tradition.

\section{German Romanticism, Jury Trial, and "Immanent law"}

Levin Goldschmidt was not the first to speak of "immanent law". "Immanent law" jurisprudence dated well back into the late Enlightenment, and began to command a large following during an intellectual rebellion against Roman law that marked the German Romantic movement. It was this Romantic rebellion against Roman law that produced the ideas whose incorporation into the U.C.C. this Note will trace.

Roman law always faced opposition during the four centuries of its use in Germany. ${ }^{18}$ But German opposition to Roman law became particularly fierce in the aftermath of the French Revolution, as ideas of popular rule and nationalism diffused through the German intellectual classes. After Napoleon's expulsion from Germany, opposition grew rapidly among lawyers who considered the use of Roman law an affront to the German Volk, the German nation. Proper law, in the eyes of these so-called "Germanist" lawyers, ${ }^{19}$ grew out of the Volksgeist, the soul of the Volk, through the slow accretion of customary practices, ${ }^{20}$ and the penetration of Roman law into the German-speaking world, by displacing customary law, had destroyed the legitimacy of the German legal order. ${ }^{21}$

These Germanist lawyers pioneered much of modern jurisprudential anti-formalism. The prime target of the Germanists were the influential

18. See generally P. Bindir, Dil: Rhzi:PITON DFs RÖMIschen REchts IM URTEIL. DER DeUTSC:Hin Rrcihiswissinsc:hafr (1979) (tracing German attitudes to Roman law); G. Strauss, LAw, Resistance, and tht: Siatr: The. Opposition to Roman Law in Reformation Germany (1986) (tracing hostility during the first century of the use of Roman law in Germany). For the general history of the gradual displacement of local German law by Roman law, see F. WIEACKER,

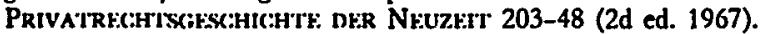

19. On the Germanist movement, see generally F. WIEACKKR, supra note 18, at 403-12. For detailed accounts of the beliefs of the Germanists, see J. ROCKR:RT, A.L. REYschers LEBEN UND

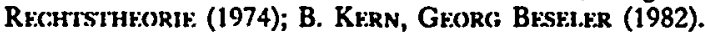

20. English-language treatments often betray difficulty in distinguishing the position of the Germanists-that the Volksgeist, and accordingly customary law, must rule in Germany-from that of Savigny. See, e.g., G. Sirauss, supra note 18, at 57. Savigny, like the Germanists, believed that the Volksgeist was the ultimate sovereign source of law. But he also believed the Volksgeist was in a state of exhaustion, and could no longer produce law. Accordingly, said Savigny, the professors of Roman law must make law for the Volksgeist. See Savigny, Vom Beruf unserer Zeit für Gesetzgebung und Rechtswissenschaft, in ThIBAUT UND Savicony 175 (H. Hattenhauer ed. 1973) (1814).

21. In particular, Germanists feared for the well-being of the peasants. For a familiar statement of the Germanist belief that customary law served the interests of the poorer Volk, see Marx, Debates on the Law of Thefts of Wood, in 1 K. Marx \& F. Engels, Collected Works 224, 230 (C. Dutt trans. 1956) (1842). 
professors of Roman law, who were the authors of dense, elegant, systematic treatises. ${ }^{22}$ In their struggle to preserve the Volk from these university systematizers, the Germanists mounted a philosophical attack designed to poison the rule of systematic treatises at its jurisprudential root. The Germanists maintained that the law of any given case should not be formalistically deduced from principles; rather each case should be decided according to the "Natur der Sache"-the nature of the matter. ${ }^{23}$ It was this Natur der Sache jurisprudence to which Goldschmidt's "immanent law" passage belonged. ${ }^{24}$ Indeed, much of modern anti-formalist legal thought had its origins in the Germanist attack on systematic jurisprudence in the chaotic Germany of the post-Napoleonic period. ${ }^{28}$ The Germanist parentage of modern anti-formalism is particularly important for the case of Llewellyn: In Llewellyn's work, the anti-formalism that had its origins in Germanist Natur der Sache thought never lost its popular-nationalist tinge.

The Germanists had not only a jurisprudential, but also an institutional program. The heart of "immanent law" jurisprudence lay in the attempt to establish criminal jury trial as an alternative to the system of CanonRoman criminal law, a system in which trained judges evaluated evidence according to a complex set of rules, the so-called "gesetzliche Beweisregeln."2e Many Germans, among whom Hegelians were particularly

22. For a recent survey of the systematic Roman law scholarship of the nineteenth century, known as "Pandektistik," see E. POL.AY, Ursprunc, ENTwicklung UNd UNTERGang DER PandekTistik (1981).

23. The doctrine of the "Natur der Sache" had a complicated history, which is summarized by Mayer-Maly, Natur der Sache, in 3 HANDWORTrRBUch ZUR DFUTschen Rrchtscieschichtre 917 (1984). The doctrine, originally an ancient Roman invention, was revived by Montesquieu. See C. Secondat, Baron de Montesquir., ThE SpIrit of The Laws 1-7 (T. Nugent trans. 1949) (1748). In Germany, the doctrine was adopted first by late Enlightenment thinkers, then by Germanisten.

24. Llewellyn omitted from his translation of the "immanent law" passage, quoted in COMMON LAW TRADITION, supra note 16, a sentence declaring that the jurisprudence of the "immanent law" was "Natur der Sache" jurisprudence: "Es besteht cin Natur- oder Vernunft- oder ideales Recht (jus naturae, naturale), das ist die Gesammtheit derjenigen Rechtssätze, welche der vernünftigen Natur der jederzeitigen Lebensverhältnisse, der Natur der Sache (naturalis ratio) entsprechen." L. GoLDsCHMIDT, supra note 16 , at 302.

25. Romantic anti-formalism influenced the late nineteenth-century anti-formalism of the socalled Free Law Movement. See infra note 72. The Free Law Movement, in turn, influenced American realism. See Herget \& Wallace, The German Free Law Movement as the Source of American Legal Realism, 73 VA. L. Rev. 399 (1987). On American realism as a revolt against formalism, see R.S. Summers, Instrumental.ism and American Legal. Theory 136-59 (1982). For the German influence on American formalism, see Hoeflich, Law and Geometry: Legal Science from Leibniz to Langdell, 30 AM. J. Lk.cial. History 95 (1986).

26. The revolt against the "gesetzliche Beweisregeln" and the campaign for the criminal jury is traced in Landau, Schwurgerichte und Schöffengerichte in Deutschland in 19. Jahrhundert bis 1870, in The Trial. Jury in Engi.and, France. and Germany, 1700-1900 (H. Coing ed. 1988) (forthcoming). My thanks to Professor J. Langbein, who provided me with a copy of this article. See

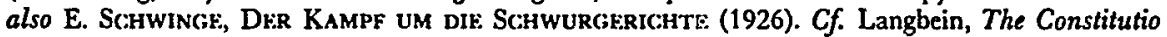
Criminalis Carolina in Comparative Perspective: An Anglo-American View, in Strafrecht, STRAFPROZESS UND Rlzz.PIION 222-23 (Landau \& Schroeder eds. 1984). For the earlier history of the "gesetzliche Beweisregeln" and their decline after the Middle Ages, see J. Langrein, Torture and the LAw of ProOf, 3-8, 45-60 (1976). 
prominent, ${ }^{27}$ believed that jury trial and "immanent law" jurisprudence were fundamentally more just than was application of learned doctrine. Jury decisions arose from the soul of the jury, just as customary law arose from the soul of the whole people. As one lawyer put it in 1835, "Citizenjurors have an innate feel for law, which is perfect, which dwells fully prepared in the soul of every human being, and which needs no schooling or academic training ..."28 A whole mystical canon grew up around the interpretation of jury decision-making: juries had a "total impression" and saw the case in its individuality. ${ }^{20}$ Juries spoke from an "intimate conviction"so that was at once ineffable and infallible; they could never give reasons for their decisions, which flowed from unverbalizable intimations of the soul. ${ }^{31}$

It was this institutional aspect of their campaign that saved the Germanist program from being an ineffectual mysticism of the Volk. The establishment of jury trial was a real possibility in early nineteenthcentury Germany. Despite the introduction of Roman law, the medieval lay courts of Germany, the so-called "Schöffengerichte," still existed in some places. ${ }^{32}$ There was also a French form of jury, in practice the form most familiar to German lawyers. ${ }^{33}$ Finally, there was the English model, vocally admired by many Romantics. ${ }^{34}$ This Romantic interest in English institutions produced an irony: what Llewellyn was to borrow from the Romantics, the Romantics themselves had, in some measure, borrowed from the Common Law.

27. See Landau, supra note 26; E. Sc:HWIN(r), supra note 26, at 104.

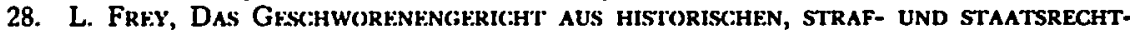

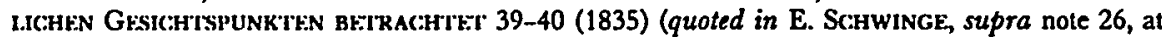
119): "Ein innatives Rechtsgefühl, das, keiner schulgerechten, wissenschaftlichen Ausbildung bedürfend, vollendet, fertig in der Seele eines jeden Menschen lebt ..."

29. E. Schwincik, supra note 26, at 78, citing GUTAC:HTEN DER IMMEDIAT-JUSTIZ-COMMISSION OBER DAS GRS:HWORFNFN(BHRICH" (1819).

30. For the carlier history of "intime conviction," which was not originally associated with jury trial, see J. LANGBbin, supra note 26 , at 48.

31. Cf. E. St:Hwincie, supra note 26, at 85, 92.

32. For the nineteenth-century revival of Schöffengerichte (largely a phenomenon of later in the century), see Landau, supra note 26.

33. On the French jury see Landau, supra note 26; E. Schwinge, supra note 26, at 2-5.

34. Admiration for English jury-trial could already be found in the pre-Romantic J. J. Möser. 4 J. Möstr, Paitriorils:ht: Phaniastien 27 (1797): "In den mehrsten Ländern werden die Verbrecher noch nach abstrahirten Gesetzen verdammı; aber in England erkennen zwölf Totaleindrücke über die concrete Tha!" (cited in E. Sc:Hwinck, supra note 26, at 87). Typical of the post-Napoleonic period was the great political thinker R. von Mohl, to whom Blackstone seemed to propagate "ein juristisches Evangelium". 2 R. VON MOHL, LI'riRA'TURGisc:HICHTE. DER STAATSWISSENSCHAFTEN 40 (1846) (quoted in T. WIL.HFi.M, DiF: ENGI.ISCHF. VERFASSUNG UND DER VORMärzLICHE DEUTS:HF. LIBERAI.ISMUS 17 (1928)). For the Lousianian Edward Livingstone's influence, see Landau, supra note 26. Some nationalistic Germans objected to the influence of an English institution, but it was widely believed that the English jury trial was a surviving common Germanic institution, and not a solely English one. For differing views among Romantic scholars, see K. ROGGE, ÜBER DAS GerichtswFst.N drk Gromanke (1820) (jury a common Germanic institution), and G. vON MaURER, GrST:HI(;HT: DES AI:T(itrmanisc:HeN Gerichtsverfahrens 107 (1824) (jury specifically of English origin). Among German politicians, the consensus was that jury trial was generally Germanic rather than specifically English. E. Scinwincie, supro note 26, at 54, 65 n.5. 


\section{Romanticism and Commercial Law to 1848}

Of course, Llewellyn borrowed directly, not from Romantic criminal law thought, but from Romantic commercial law thought. Nevertheless, Romantic commercial law thought very much belonged to the "immanent law" tradition associated with the criminal jury. Indeed, the later decades of the Romantic movement saw the growth of a remarkable conviction that commercial codification could satisfy the nationalistic yearnings of German lawyers.

Romantic legal thinkers devoted part of their attention to commercial law from the first years of the movement. Commercial law was attractive to the Romantics, for it had in earlier centuries been a largely customary system, independent of learned systems of law. ${ }^{35}$ Moreover, there was a lay trial tradition in commercial law. Just as there were still Schöffengerichte ${ }^{36}$ in a few sections of Germany, there were also lay commercial courts in a few Northern cities. ${ }^{37}$ As was the case with the criminal jury, the French occupiers had introduced a form of lay commercial court. ${ }^{38}$ The English model was present as well: it was in the late eighteenth century that Lord Mansfield began to draw on lay jurors in hearing commercial cases. ${ }^{39}$

The law merchant was already attracting Romantic interest in the 1780's. J.G. Büsch, ${ }^{40}$ a trader from Hamburg and universal historian of commerce, began promoting the idea that commercial cases had a special commercial "Natur," and that special commercial courts were indispensable."1 Ordinary judges were only confused by commercial law-indeed, the more non-commercial law they had learned, the more confusing they found commercial litigation. ${ }^{42}$ In commercial matters, judges must "distance themselves from all juristic notions and simply use their common sense, in order properly to grasp and master the nature of the transaction [die Natur des Geschäftes]. . . ."4s

This was no more than a commercial lawyer's version of Natur der

35. Cf. supra note 11.

36. On Schöffengerichte, see supra note 32.

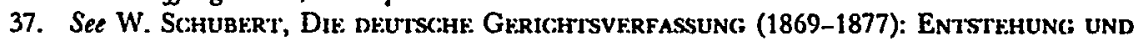
QUELLEN 181 (1981).

38. See id. at 181-82; Silberschmidt, Der Einfluss des fremden Rechts auf die deutsche Gerichtsverfassung in bürgerlichen Rechtsangelegenheiten, in 3 RH:INISCHE Z:TrsciRIFI FÜR ZIVII.RFCHT UND PROZzsssr.chr 164-66 (1911).

39. For the influence of Mansfield in Germany, see infra note 61.

40. For the importance of Büsch, I rely on 1 L. Gol.Dschmint, Hannbuch DES HandelSRECHTs 195-96 (2d ed. 1864). It is significant for the influence of English legal forms in Germany that Büsch was one of the first Germans to travel to England for the purpose of studying the political

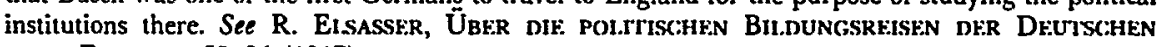
NACH ENGI.AND 53-56 (1917).

41. 2 J.G. Büsci, Theoreitsch-Praktische, Darstili.ung de.R Handiung 364 (1792).

42. Id. at 365 .

43. Id. at 366 . 
Sache jurisprudence.4 But Büsch had an idea of Natur der Sache justice that was different in one crucial respect from the idea of the Natur der Sache current among Romantics in other fields. While he regarded comercial law as customary law, he regarded it not as the creation of the Volk, but as the creation of the community of merchants, an independent body with its own consciousness and its own customary law. Because he believed that the law merchant was the creation of the community of merchants, rather than of the whole Volk, Büsch was able to give definite substantive content to the "nature" of commercial matters. Commercial custom, wrote Büsch, was not based merely on vague intuitions of what was right; commercial custom was based on "good faith and honest dealing." pioneered by Büsch, extending the Germanist ideology of customary law, jury trial and Natur der Sache jurisprudence to commercial law, ${ }^{48}$ arguing that the revival of lay commercial courts would put an end to the "exclusive domination of learned lawyers." 47 To these lawyers, commercial law and "immanent law" reasoning seemed to hang together: they were both products of the pre-formalist world of the Volk.

\section{1848 AND GoLDSCHMIDT}

A critical new turn in the history of this Romantic commercial law tradition came in the aftermath of the Revolution of 1848, with the first appearance of a peculiar German idea: the idea that commercial codification could further the rule of the people. In 1848, the campaign for jury trial and for decision-making on the basis of the "total impression" of the Natur der Sache achieved a kind of victory - but not the victory that the Romantics wanted. The revolutionaries of 1848-who were disproportionately Germanist Romantics ${ }^{48}$ - succeeded in introducing jury trial for criminal cases into virtually every German state. ${ }^{99}$ But the form of jury

44. Büsch, like other Romantics, wished to preserve law from the encroachments both of Roman law and of legislation. See id. at 359-60.

45. Id. at 357-58 (merchants must abide by standards of honest dealing and good faith rather than by statute).

46. For a survey of German debates about commercial law and the rise of Natur der Sache argumentation as an alternative to the use of Roman commercial law, see Köbler, Die Wissenschaft des gemeinen deutschen Handelsrechts, in 1 Wisstinsciafr und Kodifikation des Privat-

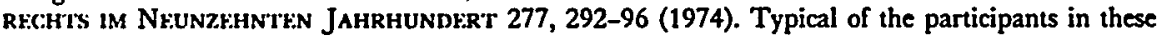
debates was F.A. Biener, who made himself both a leading commercial lawyer and a leading advocate of jury trial on the English model. See, e.g., 1 F. BifNer, ABHANDLUNGEN AUS DEM GebieTE DER Rec:HIsciss:hic:H'rt: (1846), a book of two essays treating, respectively, the rise of the English jury and the development of a medieval customary commercial law. On the particularly important commercial lawyer of the era, Karl Einert, see Bergfeld, Die Papiergeldtheorie Karl Einerts und ihre Bedeutung fïr das Wechselrecht, 17 IUS COMMUNE, SONDERHEFT 1 (1982).

47. This was the judgment of a Cologne judge in 1850 , who is quoted in W. Schubert, supra note 37 , at $182-83$.

48. See generally W. Sifmann, Dir: Frankfurtir Nationalversammlung (1976).

49. Only Austria and Altenberg did not introduce jury trial in the wake of the Revolution. E. St:hwincie, supra note 26, at 155. Cf. E. KriRn, Grschichte des Gerichtsverfassungsrechts 
trial that was introduced was the French adaptation of English jury trial, in which the state drew up jury lists. ${ }^{50}$ Horrified Romantics found themselves to have sponsored a system in which the jurors were overwhelmingly wealthy burghers, professionals, and academics-men far removed from the Volk as they conceived it. ${ }^{51}$ This disappointment was compounded by another great disappointment of the Revolution: the revolutionaries failed to expel Roman law. With the failures of 1848, Romantics began to turn to revived Schöffengerichte. . $^{\text {2 }}$ They also began to turn their attention to the one area of German private law in which Roman law reasoning did not dominate: commercial law. Commercial law focused the attention of German lawyers throughout the decade of political disappointment after 1848, and in 1861 the Romantics succeeded in producing a commercial code based, by and large, on the Romantic conception of the law merchant.

The leading figure in the commercial codification of 1861 was Levin Goldschmidt. ${ }^{\circ 3}$ A Jew who overcame great prejudice in making himself the leading commercial lawyer in Germany while still in his twenties, ${ }^{54}$ Goldschmidt was a man of unique learning and sophistication who in many ways departed from the work of his predecessors. ${ }^{\text {s5 }}$ Nevertheless, in essence he held to the old Romantic tenets. Merchant juries, declared Goldschmidt, must be established for commercial cases, for only merchant jurors were properly attuned to commercial custom. ${ }^{\text {B }}$ Commercial custom grew out of businessmen's commitment to honest business dealing and their sense for the ins and outs of business practice, ${ }^{57}$ and courts could best serve the rule of commercial custom by judging according to the Natur der Sache. ${ }^{\mathrm{ss}}$. The rule a court established on the basis of the Natur der Sache would almost always jibe with the feel $[\text { Takt }]^{59}$ and conscious-

75-77 (1974).

50. The history of the adoption of French jury trial by the Frankfurt Parliament is traced by E. SCHWincie, supra note 26, at 129-130.

51. See E. Sc:Hwinci., supra note 26 , at 130.

52. See Landau, supra note 26.

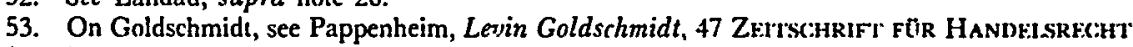

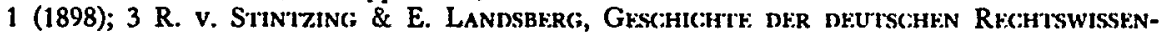
SCHAFT pt. 2, at 938-49 (1910). For the history of the commercial codification of 1861, see H. THör.,

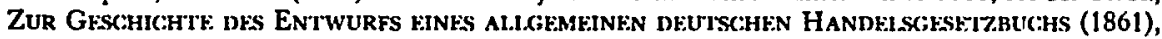
and L. Got.pschmint, supra note 40, at 94-182.

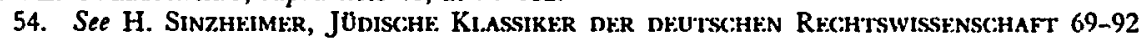
(1938).

55. In particular, Goldschmidt was more willing than his predecessors to concede that there had been important commercial relations in Antiquity, and therefore that Roman law had some contributions to make to commercial law. Nevertheless, he insisted that commercial custom was the fundamental source of commercial law. L. Gol.nschminr, supra note 40, at 11, 223-24.

56. Id. at 77-78. Goldschmidt was, however, critical of those who believed that commercial courts alone, without any guidance from written sources, could produce a satisfactory commercial law. Kritik, supra note 16, at 108.

57. L. Got.Ds:Hmidr, supra note 40 , at 220.

58. Id. at 218 .

59. For the late Romantic idea of "Taht," see 3 M. Lazarus, DAs LEBrin DFR SEFl.e 3-65 (1855). 
ness [Bewuptsein] of the merchant estate, and would establish itself as a customary norm. ${ }^{60}$ Merchant legal consciousness was the true basis of commercial law, and commercial courts, medieval in origin, were "judicial organs of merchant legal consciousness".61

This was the tradition of Büsch. But one feature was new: the introduction of Germanist nationalism into commercial law. Post-1848 Romantics, Goldschmidt first among them, were convinced that the establishment of lay commercial courts would represent direct rule for the Volk, the rule the revolution had failed to erect. ${ }^{62}$ Goldschmidt insisted that a true commercial law would promote the rule of the whole Volk: In his view, the merchant estate had evolved, or could evolve, to represent all the Volk. ${ }^{\text {s3 }}$ Thus it was an imperative of popular rule that commercial custom should, in case of conflict, take precedence over statutory provisions, for commercial custom represented the will of the Volk:

[T] The true importance of customary law in our age, with its orgy of statute-making, becomes apparent, when it is necessary to oppose an altered will of the Volk to the inflexible will of the legislator. Custom without the power of derogation is meaningless ... . Unconditional free play for custom is a cardinal point for the desired new phase of commercial law. ${ }^{64}$

Goldschmidt's "desired new phase of commercial law" would thus introduce into law what the Revolution had failed to introduce: the "will of the Volk."

Goldschmidt managed to incorporate most of his vision into the 1861 Handelsgesetzbuch ${ }^{\text {os }}$ the first major common code of the German states and the only code whose drafting committee was not dominated by Roman lawyers. ${ }^{\text {Bb }}$ The Commercial Code reserved a place for custom as a source

60. L. Got.os:нмtir, supra note 40 , at 218 n.2.

61. Id. at 242-43. Note that Goldschmidt retained the Romantic fondness for English legal institutions. The English understood the inevitably universal character of commercial law, id. at $210 \mathrm{n} .2$, and they had the sense and ingenuity to swear in special merchant jurors in commercial cases (Goldschmidt was thinking here of Lord Mansfield), id. at 77. For another example of the lasting conviction among Germans of the time that the English (along with the Americans) were the true fathers of customary commercial law, see F. NoBAc:K, Dik. HANDkis-USANZEN 5 (n.d. [1857]) (English "erste Handelswolk der Welt").

62. See, e.g., Statement of Deputy Völk of Bavaria, quoted in W. SCHUBERT, supra note 37 (commercial courts a step toward the "evolution" of popular rule).

63. L. Gol.Dsc:нminr, supra note 40, at 228-29 \& n.7.

64. Kritik, supra note 16, at 113:

[D]ie wahre Bedeutung des Gewohnheitsrechts in unserer heutigen gesetzgebungslustigen und an Gesetzen überreichen Zeit zeigt sich da, wo es gilt dem unbeugsamen gesetzgeberischen Willen die veränderte Volksüberzeugung wirksam entgegenzustellen. Usance ohne derogatorische Wirkung ist ein leeres Wort .... Völlige Freigebung der Usance ist eine Cardinalfrage für die erstreble neue Phase des Handelsrechts. (emphasis in original).

65. See generally Köbler, supra note 46.

66. See id. On the unsuccessful attempts of Roman lawyers to create a modern Roman commercial law, see Whitman, The Last Generation of Roman Lawyers in Germany, in GreEx AND LATIN 
of law-something no German statute had done for a century and a half. ${ }^{6 z}$ Moreover, the new commercial order eventually received the kind of special court Goldschmidt desired: ${ }^{68}$ In 1879 the new German Empire established special commercial courts. ${ }^{89}$ Goldschmidt's Code for the Volk became a reality.

But how much reality could there be in a commercial code intended to further popular rule? Commercial law had taken on a democratic/nationalist coloring only because the disappointments of the Revolution had left Germanist lawyers nothing to turn their energies upon except commercial law. Nevertheless, unreal as it may seem, Goldschmidt's merchant Volk had come to stand in for the German nation, and the merchant jury had become the instrument of popular rule.

\section{Llewellyn's Revival of Romantic Thought}

Llewellyn only began drawing on the century-old Natur der Sache tradition in 1931-32, when he was a visiting professor at the University of Leipzig. But the way had long been prepared for Llewellyn's embrace of German thought, both by Llewellyn's own German education and by fifty years of American interest in German law. Like scholars in many fields, leading American lawyers-among them Holmes ${ }^{\mathbf{2 0}}$ and Pound ${ }^{\mathbf{7 1}}$-had been drawn to German thought after 1870 , and indeed to the Natur der Sache tradition in particular ${ }^{23}$; Llewellyn was only the last of a distinguished line. Much German experience made it possible for Llewellyn to continue what Holmes and Pound had begun. Sent to a German secondary school, Llewellyn served in the German army in 1914-and indeed was awarded the Iron Cross. ${ }^{73} \mathrm{He}$ continued to cultivate his German connections during his forty years as a practitioner and professor, devoting

Scholarship in History (C. Dionisoti ed. 1988) (forthcoming).

67. HGB art. 1 (1861): "In Handelssachen kommen, insoweit dieses Gesetzbuch keine Bestimmungen enthält, die Handelsgebräuche und in deren Ermangelung das allgemeine bürgerliche Recht zur Anwendung."

68. For the role of Goldschmidt in the eventual establishment of lay commercial courts, see $W$. SCHUBERT, supra note 37 , at 188.

69. See generally W. Silberschmidr, Diw Deutsche SondergerichtsbarketT in HaNdelsUND GeWERBESACHEN 189-232 (1904). In these courts, attached to the courts of the German states, two lay merchants joined a learned judge in panel. See id., 206-08, 209-13.

70. See 2 M. Howk, Jusitce Ol.Iver Wendil. Holmes 150-55 (1963).

71. See D. Wigdor, Roscon: Pound 114-16 (1974).

72. For a survey of later nineteenth- and early twentieth-century German Free Law movement and its influence in America, see Herget \& Wallace, supra note 25. For a brief account of the development of the Free Law movement, with its roots in part in the Natur der Sache tradition, see K. LaRenz, Methodent.ehrf. der Rechiswissenschaft 59-62 (1983). The rise of the Free Law movement should be seen against the background of the slow growth of German acceptance of precedent-based law-making traced by J. DAwSON, THF. ORAcitis of THF LAW 432-502 (1968), and H. Weller, Dit: Bedrưtung; dir Präjudizien in dem diutschen Rechtsverständnis (1979).

73. On Llewellyn's German experience see W. Twininc; supra note 13, at 89-90, 106-09, 479-87; Rehbinder, Finleitung des Herausgebers, in K. Ll.wWHI.YY, RECHT, REchtsLEBEN UND GESELLSCHAFt 9-11 (1977) (posthumous publication of manuscript originally written in 1932). 
much of his energy to introducing American legal thought to the German world, and German legal thought to the American. ${ }^{74}$

Nevertheless, in his early thinking about commercial law, Llewellyn did not yet draw directly on German tradition. In 1925 he was already campaigning for "specialized commercial courts." But he considered the use of such commercial courts a general European practice, and not a specifically German one. ${ }^{75}$ Llewellyn renewed his ties with Germany in 1928, when he traveled to Leipzig to give a series of lectures, later published in book form, on the American case-law system. ${ }^{26}$ But these lectures did not yet show any sign that Llewellyn had seen models for America in the German legal order. By 1931, however, Llewellyn had begun to investigate German legal thought more energetically. ${ }^{77}$ In that year Llewellyn returned to Leipzig and began an avid Germanization of his legal thinking. His 1931 sojourn in Germany brought with it Llewellyn's acceptance of the Romantic commercial law tradition.

The Weimar Republic was, of course, in its dying months during the academic year 1931-32. Llewellyn arrived in a Germany caught in the grip of deepening political mysticism, of adulation of things German. Romantic nationalism had revived, but it was a Romantic nationalism transformed, the Romantic nationalism of what is commonly called "völkisch" politics. ${ }^{78}$ Germany in 1931-32 was experiencing simultaneously the complete collapse of democracy and the last outburst of Romantic enthusiasm

74. Llewellyn's efforts to make the American Volk comprehensible to the German included translations of folk songs, among them "Git Alo-0-ong Little Dogies!" An excerpt, taken from Section D (German Materials) Folder XIII of the Kari. Li.fwel.I.YN PAPfers at the University of Chicago Law Library [hereinafter KLP], follows:

Ich ritt eines Morgens zu meinem Vergnügen,

da treff ich 'nen Cowboy, der reitet allein,

ihm klimpern die Sporen, aus vollauter Kehle

wie er vorbeireit[e]t, singt er diesen Reim:

Hu pi tei-jei-jo, Marsch, marsch lütte Stierchen,

Fur' ist das Unglück, ich nenn es nicht mein.

Hu-pi-tei-jei-jo, marsch, marsch lütte Stierchen

Euch wird Wyoming ein neues Heim.

O-hei-o-u-hu, O-hei-o-u-hu! Hu ...Hu.

75. Llewellyn, The Effect of Legal Institutions upon Economics, 15 AM. EcoN. Rev. 665, 669 n.13 (1925) (praising European "specialized commercial courts").

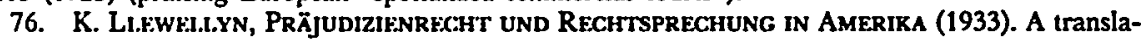
tion of Llewellyn's methodological introduction to this collection of cases is now in preparation. My thanks to Professor Paul Gewirtz, who provided me with a copy of the English version. A shorter, privately printed version of Llewellyn's lecture-course can be found in the collection of Harvard Law Library: K. Li.f.wi.l.I.YN, EINfOhrung in DAS AMERIKanische PräjudizienRechtswesen (1928). Llewellyn later declared that his 1928 lectures were the germ of The Common Law Tradition. ComMON LAw TRADrton, supra note 16, at 512.

77. In 1931, Llewellyn declared it "high time that American legal thinking should arrive at a conscious and sociologically defensible working position in regard to European legal thought," Llewellyn, What Price Contract? 40 YAl.E L.J. 704, 729 n.54 (1931), and made use of a number of German works. Id., at 707 n.9, 706 n.6, 720 n.43 (citations to R. Ehrenberg, M. Weber, E. Ehrlich, H. Isay).

78. For English-language discussions of "völkisch" politics, see, e.g., F. STERN, The Poltrics OF Cultural. Dispair (1961); W. Laqueur, Wrimar 78-109 (1974). For a treatment linking early nineteenth-century Germanist thought to the rise of Nazism, see G. Mosse, The Crisis of GermaN IDEOLOXYY (1964). 
for the German Volk. Utter lack of faith in democratic institutions and unbounded love of the Volk combined to produce strange results in German legal thought: Lawyers came to believe that they themselves embodied the Volk. Perhaps the best example of the Weimar faith that lawyers and Volk could be one was a book Llewellyn cited in 1931:78 Rechtsnorm und Entscheidung, by Hermann Isay. To Isay, who still believed, with the old Romantics, that the basis of law was "Rechtsgefuihl," innate feel for law, ${ }^{80}$ it was imperative that the Volk have a Führer, who could embody the legal sensibility of all. ${ }^{81}$ True Führers were things of remote Antiquity. But in the modern world their place had been taken by judges:

[In] the modern law-based state . . . the role of Führer in the realm of legal life is entrusted to a select, independent professional order. Thus, in modern states, things depend decidedly on the Rechtsgefiuhl of the judges. But things depend on their Rechtsgefuihl as the Führers of the Volk in this realm. This means that they must maintain this feeling, this "feeling of oneness" with the Volk and its sensibility. ${ }^{\text {s2 }}$

"Woe the Volk!," added Isay, "whose judges would lose touch with the Rechtsgefuihl of the majority of the Volk." "8s Isay was typical of the Germany to which Llewellyn returned in 1931 after a two-year absence: Love of the Volk was absolute, but confidence in the Volk's power to master its own fate was minute. German lawyers responded by claiming that the legal profession itself must rule for the Volk.

Llewellyn, always receptive to exaltations of the place of law in society, surrendered himself, in some measure, to this lawyers' mysticism of the court as Volk. "Volkisch" thinkers spoke of the dim inexpressible convictions and yearnings of the Volksgeist. So did Llewellyn (though to be sure Llewellyn was both subtler and more respectful of the rule of law than were most "völkisch" politicians): As Llewellyn wrote in 1932, law was indeed somehow linked with the convictions of the Volksgeist-though the

79. See supra note 77.

80. H. Isay, Rechisnorm UND EnTscheidung 5 \& passim (1929). Note, however, that Isay was leery of the old phrase "Natur der Sache," id. at 81-82, and should not be casually labeled a mere vulgar late Romantic.

81. Id. at 115-16 (Führer embodies collective experience of the community).

82. Id.:

[D]en modernen Rechtsstaat, in dem die Führung auf dem Gebiet des Rechtslebens cinem unabhängigen ausgewählten Berufsstande anvertraut ist. Im modernen Staat kommt es also entscheidend auf das Rechtsgefühl der Richter an. Aber auf ihr Rechtsgefühl als der Führer des Volkes auf diesem Gebiete. Das bedeutet, da $\beta$ sie diese Fühlung, die 'Einsfühlung' mit dem Volke und seinem Empfinden behalten müssen.

For another example of the common cult of the Führer among German lawyers of the period, see $W$. Gi.uncilir, Prot.fiomina zUr Rrchispolirtik (1931), cited in Radbruch, Legal Philosophy, in The. Legal. Philosophifs of Lask, Radbruch, and Dabin 117 (K. Wilk trans. 1950).

83. H. IsAY, supra note 80, at 116: "[W]ehe dem Volke, dessen Richterstand in seinem Rechtsgefühl sich von demjenigen der grossen Mehrheit des Volkies entfernen würde." 
Volksgeist alone did not create law..$^{84}$ Judges were always "powerfully" conscious of "customary instinct, a craftsmanlike, dimly sensed, inherited feel for justice"-though judges nevertheless did apply rules of law. ${ }^{\mathbf{8 s}}$ Llewellyn thus showed himself to be a cautious admirer of the reviving Romantic German Volk. He also showed himself to be sympathetic with the "völkisch" longing for leadership: Legal certainty and social stability were always weak, he wrote, "in an age without a Führer." Romantic idea had been implanted in his mind: A kind of mystical democracy could be erected if lawyers had the courage to remake the constitution of the courts.

As Llewellyn absorbed his heady dose of the Romantic nationalism circulating through the German intellectual world, his perception of commercial law was altered. German commercial law still largely took the form that Goldschmidt had conceived for it: Although the criminal jury had been abolished in $1924,{ }^{87}$ Germans continued to include lay merchants in commercial cases. ${ }^{88}$ This German form of justice clearly excited Llewellyn: he declared that Americans would do well to imitate the wise German practice of relying on men knowledgeable about commerce in commercial cases. ${ }^{89} \mathrm{He}$ began (but never finished) an English-language typescript that reviewed in some detail one crucial aspect of the German style of customary law-finding in commercial cases. ${ }^{90}$ The Chambers of Commerce which supplied the lay judges in German commercial cases had begun to publish collections of commercial opinions. To Weimar lawyers, these collections represented nothing less than "codified commercial custom." " Llewellyn, too, was excited by these late Romantic compilations: they constituted, he wrote in an enthusiastically underlined phrase, a lay institution "which can, in its way, set precedent?" In the empha-

84. K. Li.tiwt.l..YN, supra note 73 , at 44.

85. Id. at 57. Like Isay, Llewellyn thought rule of law less necessary in simple societies: A Kadi was inevitably governed by the consciousness of the Volk. Id. at 118.

86. Id. at 69 (describing instability in "eine führerlose Zeit").

87. See E. KEkN, supra note 49, at 161-64.

88. The only slight change in the organization of the commercial courts had come in 1909 . See $O$.

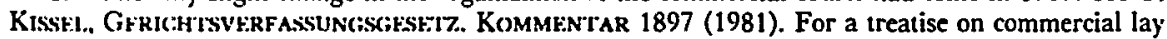
courts in the year of Llewellyn's visit to Germany, see E. REIMrR \& R. MußFFi.D, Dif KAUfMänNi-

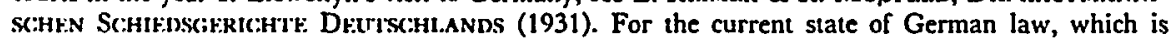
fundamentally unaliered from what Llewellyn witnessed, see GVG $\$ \S$ 93-114.

89. K. Li.twil.t.y , supra note 73, at 101 n.11.

90. Llewellyn. On Scratching Acquaintance with the German Law of Sales (1932) (unpublished fragment in Section D (German Materials), folder V of KLP, supra note 74) (title of typescript, originally "Realism and (omparative Law," altered by hand).

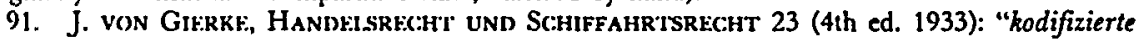
Handelsgebräuche".

92. Llewellyn, supra note 90 , at 29-30:

The German courts have a practice, when they need knowledge of such custom, of procuring an opinion from some relevant commercial body - a trade association or chamber of commerce. Such opinions are taken very seriously, by those who render them (the opinions of the Berlin Chamber of Commerce are published from time to time) and by the courts. In place of paid 'experts', sel[e]cted for their willingness to testifiy [sic] 'properly' quite as much as for their knowledge; in place of single men's haphazard experience; in place of the accident as to 
sized phrase could be read the idea that would guide Llewellyn's work on the U.C.C. eight years later: the old customary law merchant could live again. The factual determinations of merchants, collected and ordered, could compose an accretionary corpus of "codified custom," a true evolving law. If Americans could remodel their commercial law on German lines, they would rejoin the great tradition of the "lex mercatoria."

\section{The Drafting of The U.G.G.}

The opportunity to remodel American commercial law did not arrive, however, until some years after Llewellyn left Germany. From 1937 on, Llewellyn busied himself with a campaign for the reform of American commercial law, ${ }^{24}$ but it was only in 1940 that drafting of the U.C.C. began. By then, much had happened, of course, to drive the German experience from Llewellyn's mind. Americans were caught up in the disorientation of their own profound legal and social reordering, the New Deal, and Llewellyn himself had led the rise of a newly assertive and newly influential legal realist movement. These changes left their mark on Llewellyn. There was little, in his work on commercial reform in America, of the German mysticism about the simultaneous omnipotence and impotence of the Volk, little talk of the need for Führers (even if, to Llewellyn's disgust, some Nazis apparently regarded him as "a fascist and a pillar of the fascist New Deal"). ${ }^{\text {95 }}$

whether examining or cross-examining counsel will do the better job-is set the considered view of a body of men who ought to know. On one aspect this is procedural; in another it is substantive-if there is a difference. In any event, the meaning of 'usage of trade' in a German code section and in the Sales Act takes on an utterly different light, in the light of this institution: which can, in its way, set precedent!

(footnote omitted) (emphasis in original)

93. Llewellyn believed that the German merchants had preserved intact the medieval independence that had perished in America and Britain:

It is familiar that there was once in Western Europe a more or less common lex mercatoria. The rise of rationalism [meant] that on the Continent the development of this lex mercatoria into a local commercial law, set against the local civil law. In England and for us, Mansfield put the final stamp on the proposition that lex mercatoria was to be absorbed into the common law, and made part of the law for all.

Id. at 25 (emphasis in original).

94. See generally Wiseman, supra note 1, at 477-89.

95. Letter to Karl Llewellyn from Samuel Kraus ( $\mathrm{Apr} .21,1934$ ) (in unnumbered folder entitled "American Files" in Section D (German Materials) KLP, supra note 74):

Dear Karl:

John Wolff has sent me a photostat of a Nazi comment on my review of your book [Präjudizienrecht und Rechtsprechung in Amerika]. I suppose you have seen it. What interests me is the assertion that you have been accepted as a true Nazi, fit to be amalgamated into the lifeblood of the new Reich. It also interests me because someone I know who teaches in a provincial law school has called you - and Jerome Frank and others-a fascist and a pillar of the fascist New Deal.

Llewellyn repudiated the Nazis in his response to this letter. Indeed, in the last line of his response, he could not contain his irritation at the suggestion of a link between his own views and Hitler's:

Anent your letter of the 21st: when John Dickinson tells me that my interest in a descriptive pseudo-natural science of law really comes down merely to an interest in rules of the sort he likes, I do not accept that as placing either me or my work. If any Nazi welcomes me into the 
Nevertheless, despite eight nearly revolutionary years of American history, the German experience remained with Llewellyn, and the form of realism he introduced into the U.C.C. had recognizable roots in German Romanticism. When Llewellyn accepted William Schnader's 1940 invitation to become Chief Reporter of the new Uniform Commercial Code, ${ }^{98}$ he brought with him the Goldschmidtian idea that law made by the sound instincts of merchant jurors, freed of constricting formalism, was true law of the people. As Llewellyn took up his duties, he declared his dissatisfaction with an American legal order that did not permit the establishment of special commercial courts. ${ }^{97}$ The task of commercial codification, he declared, was to find some way to integrate mercantile arbitration into American law. ${ }^{98} \mathrm{~A}$ year later Llewellyn had designed the elaborate legal machinery of Section 59 of the Second Draft of the new Sales Act, which provided for the submission of a wide range of questions to merchant jurors on the motion of either party. ${ }^{99}$ Section 59 put into legal form the

fold, I make the same remark.

When Ascoli tells me that my approach to matters constitutional is a supporting of Musso-

lini, I again take the same position. ...

What in hell is your letter about?

Letter from Karl Llewellyn to Samuel Kraus (Apr. 23, 1934) (in unnumbered folder entitled " $\Lambda$ merican Files" in Section D (German Materials) KLP, supra note 74). For Llewellyn's dislike of fascism, see also Llewellyn, The American Common Law Tradition and American Democracy, 1 J. Legal \& Pol.. Sox: 14, 21 (1942).

96. See Schnader, supra note 1 , at 4.

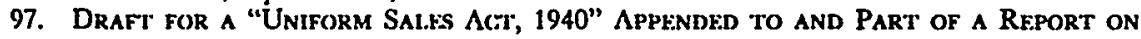

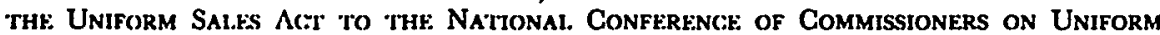
Statr: Laws 73c (1940), reprinted in 1 Uniform Commrrcial. Code: Drafts, supra note 8, at 171, 243:

One cannot follow the course of actual Sales disputes without being struck by the frequency with which single issues of fact of essentially mercantile character become crucial, and interfere with the adjustment of the whole. And one cannot follow the course of actual Sales litigation without being struck by the expense and uncertainty of litigating just such issues, especially before a jury, but also before most courts. Our political system does not afford an effective way out by way of experts or expert tribunals appointed by the courts; the guarantee is lacking that patronage may not over-balance the needed combination of competence, impartiality, speed and inex[pen]siveness.

98. Id.:

[T] he submission of narrow points of fact to arbitration, especially those narrow points on which competence makes possible speedy and accurate judgment, has never as yet been at all fully exploited, and an Act can properly suggest the possibility to the parties to a mercantile dispute, and should further the effectiveness of such procedure.

99. RkPORT and Skcond Dkafi: Thi: Reviskd Uniform Sales ACT 534 (1941), reprinted in

1 Uniform Commercial. Code: Drafis, supra note 8, at 254:

\section{Section 59. (New to Sales Act.) Submission of Mercantile Facts.}

(1) In any action arising out of a sale or a contract to sell between merchants, any issue or issues involving any of the following matters may on motion of either party be submitted specially, under Sections 59 through 59-D, to merchant experts -

(a) The effect on the terms or conditions of the sale or contract to sell, of mercantile usage, or of the usage of a particular trade;

(b) The conformity or non-conformity in quality, routing, or any other mercantile aspect of any delivery, to the duties or conditions resting on the seller, and the measure of the discrepancy, if any; and whether any defect in performance has been substantial;

(c) The mercantile reasonableness of any action by either party, the mercantile reasonableness of which is challenged;

(d) Any other issue which requires for its competent determination special merchants' 
German model Llewellyn had proposed for America in $1932 .{ }^{100}$ To be sure, Llewellyn insisted he was reviving a Common Law tradition, not importing a German one: Possibly because German institutions had an ugly association with Hitler, ${ }^{101}$ Llewellyn declared repeatedly that the scheme of Section 59 was intended, not as a Germanization of American law, but as a revival of the practices of Lord Mansfield. ${ }^{102}$

Nevertheless, Llewellyn's idea of the English commercial tradition was identifiably a German idea. In 1938, as his work on commercial codification began, he first translated Goldschmidt's ecstatic passage on "immanent law,"103 and Llewellyn's U.C.C., as it emerged, clearly owed something essential to Goldschmidt's ninety-year-old conception. The familiar § 1-103 of the U.C.C. ${ }^{104}$ should be set alongside Article 1 of Goldschmidt's Handelsgesetzbuch: "Insofar as this Code does not determine an issue, commercial custom is to be applied. In the absence of commercial custom, the general civil law is to be applied." ${ }^{\prime 105}$ Llewellyn acknowledged that the customary law order of the pre-modern world had irretrievably vanished: "[A] special 'commercial' court would not, and could not, today be abreast of the commercial practices of a hundred varied trades, as it could a hundred years ago be abreast of 'the commercial practices' of a whole city or area." ${ }^{108}$ Nevertheless, Llewellyn hoped to bring to life a whole renewed customary order, the living medieval order he thought he had witnessed in late Weimar Germany: Taken together with proposed Section 59, the U.C.C.'s general provisions, with their careful ratification of "custom" and "the law merchant," embodied a complete conception for a Romantic commercial code, a code in which the generative impulse for an ever-evolving law merchant remained with the merchants themselves, assembled in juries. ${ }^{107}$

knowledge rather than general knowledge.

Wiseman, supra note 1, at 514 n.219, notes the possibility of German influence on Section 59.

100. See supra text accompanying notes 90-92. Llewellyn himself noted that his campaign for jury-based decision-making in commercial cases represented a notable philosophical departure from his ordinary beliefs: In most cases he favored the judge as the leading law-making figure. CommoN LAW TraDrtion, supra note 16, at 319.

101. This interesting suggestion is made by Wiseman, supra note 1, at 514 n.219: "[I]n 1941 German institutions were not held in high regard in America."

102. See Rrpor't and Srcond Draft: Thr Revised Uniform Sales Act, supra note 99, at 532, reprinted in 1 Uniform Commbrcial. Code: Drafts, supra note 8, at 252.

103. The translation appeared in an unpublished translation of Hugo Sinzheimer's chapter on Goldschmidt, H. Sinzhi:ImkR, supra note 54 . W. Twining, supra note 13, at $449 \mathrm{n} .91$. Llewellyn may have used this passage when he delivered the first version of The Common Law Tradition as the Storrs Lectures at Yale Law School in 1940. Cf. Common LAw TRADITION, supra note 16, at 512. 104. U.C.C. § 1-103:

Unless displaced by the particular provisions of this Act, the principles of law and equity, including the law merchant ... shall supplement its provisions.

105. German text quoted supra note 67.

106. Rriportr and Skxond Drafi: Thr: Rkvised Uniform Sales Acr, supra note 99, at 532-33, reprinted in 1 Uniform Commercial. CoDE: Drafts, supra note 8, at 252-253.

107. Cf. U.C.C. \$ 1-102(2)(b), supra note 3 (U.C.C. intended, inter alia, "to permit the continued expansion of commercial practices through custom [and]usage ...."). 
Moreover, like Goldschmidt's proposed code of 1857, Llewellyn's proposed code was intended to do more than just restore the law merchant. Llewellyn intimated throughout his comments and memoranda that his Code was intended somehow to promote a rule of the American people through an altered form of the rule of law. Thus Llewellyn felt compelled to admit that the towns and other localities of Depression America seemed to lack the peaceful unanimity of spirit characteristic of a Romantic Volk. There was no guarantee that even a community with powerful common convictions would make those convictions felt in an expert tribunal: "There remain two other bothers. One, in a small community, is local merchant politics, 'influence', the possibly dominating character of a single, but unreasonable 'big man'. The other is the precise opposite: the failure of local informal pressures toward reasonableness and decency in judgment to reach an 'imported' expert."108 Nevertheless, as this passage suggests, Llewellyn still held true to the belief of Goldschmidt and Isay that courts could somehow embody the people. Commercial courts could give the American small-town Volk a chance to exercise pressure for "reasonableness and decency"; commercial law would be "known to be friendly, even neighborly." 109

To be sure, Llewellyn's 1940-41 conception of the "friendly . . . neighborly" Volk was not a German one. The Llewellyn of 1941 was guided as much by the social vision of Frank Capra as by the legalhistorical vision of Levin Goldschmidt; behind Llewellyn's theorizing lay a Depression-era longing for small-town cooperation and social normalcy; in which the power of the community would stand by the "little man"110 in his conflict with the "big man." But if Llewellyn had a mental picture of the American people that differed in detail from the Romantic picture of the German Volk, his hopes for commercial law were fundamentally German Romantic hopes: he was motivated, not only by a sober intellectual distrust of formalism, but by an intoxicated faith that courts could somehow speak for the spirit of the nation. Llewellyn's scheme represented, to be sure, realism of a kind. But it was realism with a democratist tinge. Rule of merchant jurors, premised on staunch anti-formalism, would be rule of the people. Commercial "reasonableness" would be a subset of the American people's "reasonableness and decency." The draft that Llewellyn laid before the Conference of Commissioners on Uniform State Laws in September of 1941 would be a code for the American Volk.

108. Rf:port AND SECond Draft: The Rfvised Uniform Sales Act, supra note 99, at 536, reprinted in 1 Uniform Commerciai. Code: Drafts, supra note 8, at 256.

109. Llewellyn, Memorandum to Executive Committee, Committee on Scope and Program Section on Uniform Commercial Acts Re: Possible Uniform Commercial Code, in KLP, supra note 74, at Section J. II. 1. b. Quoted in Wiseman, supra note 1, at 494.

110. For Llewellyn's championship of "the little man," see, e.g., Llewellyn, Bringing Legal Aid to the Little Man, N.Y.Times, Mar. 25, 1934, §6 (Magazine), at 7. 


\section{CONCLUSION}

But the commissioners did not accept Llewellyn's draft-or rather they accepted it only in a partial, indeed in a mangled, form. Discussion of Section 59 was adverse to Llewellyn's scheme. By 1942, the institution of merchant juries had vanished from the working draft of the Uniform Commercial Code. ${ }^{111}$ The loss of Section 59 was, perhaps, no great loss. One may doubt whether Llewellyn's vision of a people's commercial law cultivated by special merchant juries could ever have been realized in practice. But when the commissioners abandoned Section 59, they did not abandon a host of provisions that assumed the institutional framework of Section 59. Llewellyn's Code retained its deference to "custom," the "law merchant," "good faith" and "reasonableness." In Llewellyn's Romantic vocabulary, however, "custom," the "law merchant," "good faith" and "reasonableness" were not terms of substantive law, but procedural directives, indications to a court that it should refer its decision to lay specialists with a feel for commercial law. Without a body of laymen whose intuitions-or whose feel for business-made it possible to navigate the waters of custom, none of the old Natur der Sache theorizing had much meaning.

And indeed, faced with a code studded with reference-less procedural directives, courts flounder. The many provisions of the U.C.C. that call upon courts to decide "reasonableness" have proven a source of constant confusion. These provisions were composed on the assumption that Section 59 merchant juries would be available to develop a case-law of "reasonableness." In the absence of such juries, courts have been wholly unable to agree whether questions of "reasonableness" are to be decided by judge or by trier of fact;.,12 "reasonableness" has shown itself to be a major source of non-uniformity in the jurisprudence of the Uniform Code. Determining "custom" and "usage" has proven problematic as well: Without Llewellyn's merchant jurors, courts have had to cope with complex hearsay and burden of proof problems. ${ }^{113}$ As for the "law merchant," the phrase has become little more than a dead letter. Courts almost never refer to the "law merchant," and when they do, they treat the words as

111. For the death of the proposal for merchant juries, see Wiseman, supra note 1, at 527-528.

112. See, e.g., Flagship Cruises, Led. v. New England Merchants Nat'l Bank of Boston, 569 F.2d 699, 24 U.C.C. Rep. Serv. (Callaghan) 745 (1st Cir. 1978) (reasonableness "classic issue" for trier of fact); Gigandet v. Third Nat'l Bank of Nashville, Tenn., 333 So.2d 557, 19 U.C.C. Rep. Serv. (Callaghan) 506 (Ala. 1976) ("reasonable time" question for jury); Pace v. Sagebrush Sales Co., 114 Ariz. 271,560 P.2d 789, 21 U.C.C. Rep. Serv. (Callaghan) 490 (1977) (reasonableness not always question for jury); G \& H Land \& Cattle Co. v. Heitzman \& Nelson, 102 Idaho 204, 208, 628 P.2d 1038, 1042, 31 U.C.C. Rep. Serv. (Callaghan) 541, 546 (1981) (reasonable time may be determined as matter of law); S.C. Gray, Inc. v. Ford Motor Co., 92 Mich. App. 789, 817, 286 N.W.2d 34, 46, 29 U.C.C. Rep. Serv. (Callaghan) 417, 428 (1979) (reasonableness question of law). See generally, U.C.C. Cast: Digrst ff 1204.1 (1986).

113. Cf. J. Whrte: \& R. Summkes, supra note 5, at 103-04. 
synonymous with "Common Law" or "Equity"; $;$ "114 the idea of the ancient customary lex mercatoria, which Llewellyn hoped to see his Code revivify, has been quite forgotten.

Nevertheless, courts make do. There is no reason to suppose that commercial cases are decided any less fairly than they would be in a legal world of merchant juries. But it bears remembering that courts are only making do. Lacking merchant juries, commercial courts must work with a mystical language disengaged from the institutions that would have given it meaning. If those courts nevertheless muddle through, it is not because they are achieving what Llewellyn thought they could achieve

114. Most courts invoke $§ 1-103$ of the U.C.C. simply to justify the application of general equitable principles in commercial cases. See, e.g., Prince v. LeVan, 486 P.2d 959, 962, 9 U.C.C. Rep. Serv. (Callaghan) 367, 372 (Ala. 1971); In re Staveco Elec. Constr., Inc., 40 U.C.C. Rep. Serv. (Callaghan) 1308, 1316 (Bankr. D.N.J., 1985); Morgan Guar. Trust Co. of New York v. American Sav. \& Loan Ass'n, 804 F.2d 1487 (9th Cir. 1986) cert. den. -U.S.-, 107 S. Ct. 3214, 96 L. Ed., 701, 2 U.C.C. Rep. Serv. (Callaghan) 2d 785 (1987). R.S. Summers goes so far as to assert that $\$ 1-103$ had as its purpose, not to guarantee the continued existence of the law merchant, but to require the application of equitable principles in commercial cases. Summers, General Equitable Principles Under Section 1-103 of the Uniform Commercial Code, 72 Nw. U.L. REv. 906, 912 (1978). 
